\title{
PENGARUH PENDIDIKAN DAN PELATIHAN, DISIPLIN KERJA SERTA MOTIVASI KERJA TERHADAP KINERJA PEGAWAI DI BADAN KEPEGAWAIAN DAERAH KABUPATEN KOTAWARINGIN TIMUR
}

\author{
The Influence of Education And Training, Work Discipline and Work Motivation On \\ Employee Performance In Badan Kepegawaian Daerah Kabupaten Kotawaringin Timur
}

\section{Fitriansyah \\ Raden Biroum B}

Holten Sion

Universitas Terbuka, Jakarta, Indonesia

*email:

fitriansyah75.ut@gmail.com

Kata Kunci:

Pendidikan dan Pelatihan

Disiplin Kerja

Motivasi Kerja

Kinerja Pegawai

Keywords:

Education and Training Work

Discipline

Work Motivation

Employee Performance

\begin{abstract}
Abstrak
Tujuan penelitian ini adalah untuk mendeskripsi dan menganalisis pengaruh pendidikan dan pelatihan, disiplin kerja, motivasi kerja baik secara parsial maupun simultan terhadap kinerja pegawai di Badan Kepegawaian Daerah Kabupaten Kotawaringin Timur. Metode penelitian yang digunakan dalam penelitian ini menggunakan metode kuantitatif dengan menggunakan sampel sebanyak 36 orang pegawai yang ada di Badan Kepegawaian Daerah Kabupaten Kotawaringin Timur. Teknik pengambilan sampel yang digunakan dalam penelitian ini menggunakan sampling jenuh, teknik pengumpulan data menggunakan kuesioner / angket dengan cara memberikan seperangkat pertanyaan kepada responden, analisis data menggunakan regresi linear berganda. Hasil uji secara parsial variabel Pendidikan dan Pelatihan $(X I)$ diperoleh nilai signifikansi sebesar 0,77I > 0,05 dan nilai $t_{\text {hitung }} 0,293<t_{\text {tabel }}$ 2,036, dengan demikian Pendidikan dan Pelatihan tidak berpengaruh signifikan terhadap kinerja pegawai, variabel Disiplin Kerja (X2) diperoleh nilai signifikansi sebesar 0,002 <0,05 dan nilai $t_{\text {hitung }} 3,457>t_{\text {tabel }} 2,036$, dengan demikian disiplin kerja berpengaruh signifikan terhadap kinerja pegawai, variabel Motivasi Kerja (X3) diperoleh nilai signifikansi sebesar 0,I22 $>0,05$ dan nilai $t_{\text {hitung }} I, 590<t_{\text {tabel }} 2,036$, dengan demikian motivasi kerja tidak berpengaruh signifikan terhadap kinerja pegawai. Hasil uji secara simultan diperoleh nilai signifikansi sebesar $0,000<0,05$ dan nilai $F_{\text {hitung }} I \mathrm{I}, 999>\mathrm{F}_{\text {tabel }} 2,90$, dengan demikian Pendidikan dan Pelatihan, Disiplin Kerja, dan Motivasi Kerja secara simultan (bersamasama) berpengaruh siginikan terhadap Kinerja Pegawai dengan kontribusi sebesar $52,9 \%$ sedangkan sisanya sebear $47,1 \%$ dipengaruhi oleh variabel lain di luar variabel yang tidak diteliti.
\end{abstract}

Abstract
The purpose of this study was to describe and analyze the effect of education
and training, work discipline, work motivation either partially or simultaneously on
the performance of employees in Badan Kepegawaian Daerah Kabupaten
Kotawaringin Timur. The research method used in this study uses quantitative
methods by using a sample of 36 employees in Badan Kepegawaian Daerah
Kabupaten Kotawaringin Timur. The sampling technique used in this study used
saturated sampling, the data collection technique used a questionnaire by giving
a set of questions to the respondent, and the data analysis used multiple linear
regression. The partial test results of the Education and Training variable $(X I)$
obtained a significance value of $0.77 I>0.05$ and a tcount value of 0.293
$<$ ttable 2.036, thus Education and Training did not have a significant effect on
employee performance, the Work Discipline variable (X2) obtained a significance
value of $0.002<0.05$ and the value of tcount 3.457> table 2.036 , thus work
discipline has a significant effect on employee performance, the work motivation
variable (X3) has a significance value of $0.122>0.05$ and a tcount of I.590 $<t$
table 2.036 , thus work motivation does not have a significant effect on employee
performance. The test results simultaneously obtained a significance value of
$0.000<0.05$ and the value of Fcount II.999> Ftable 2.90 , thus Education and
Training, Work Discipline, and Work Motivation simultaneously (together) have a
significant effect on Employee Performance with a contribution of $52.9 \%$ while
the remaining $47.1 \%$ is influenced by other variables outside the variables not
studied.




\section{PENDAHULUAN}

"Pengembangan sumber daya manusia adalah upaya berkesinambungan meningkatkan mutu sumber daya manusia dalam arti yang seluas-luasnya, melalui pendidikan, latihan, dan pembinaan" (Silalahi, 2000:249). Pengembangan sumber daya manusia adalah suatu proses untuk meningkatkan pengetahuan, keahlian, dan keterampilan sesuai dengan perkembangan ilmu pengetahuan dan teknologi. Melalui pengembangan kompetensi diharapkan setiap pegawai mampu menyelesaikan pekerjaan yang menjadi tugas dan tanggung jawabnya.

Menurut Andrew F. Sikula (dalam Mangkunegara 2013: 44) menyatakan bahwa "Pelatihan adalah suatu proses pendidikan jangka pendek dengan menggunakan prosedur yang sistematis dan terorganisir, di mana pegawai non managerial mempelajari pengetahuan dan keterampilan teknis dalam tujuan terbatas".

Menurut Rivai (201I) “disiplin kerja adalah suatu alat yang digunakan para manajer untuk berkomunikasi dengan karyawan agar mereka bersedia untuk mengubah semua perilaku serta sebagai upaya untuk meningkatkan kesadaran dan kesediaan seseorang mentaati semua peraturan perusahaan dan norma-norma sosial yang berlaku".

Faktor motivasi merupakan hal yang sangat penting dalam meningkatkan kinerja karyawan, menurut Rivai (201I) "motivasi adalah serangkaian sikap dan nilai-nilai yang mempengaruhi individu untuk mencapai hal yang spesifik sesuai tujuan individu".

"Tujuan kinerja adalah menyesuaikan harapan kinerja indivudu dengan tujuan organisasi. Kesesuaian antara upaya pencapaian tujuan individu dengan tujuan organisasi akan mampu mewujudkan kinerja yang baik" (Wibowo, 201 I:48).

Berdasarkan hasil studi pendahuluan ditemukan hal - hal sebagai berikut : Hasil Sasaran Kinerja Pegawai Badan Kepegawaian Daerah Kabupaten Kotawaringin Timur Tahun 2019 menunjukkan nilai Prestasi Kerja Pegawai rata-rata sebesar 84,37\%. Berdasarkan data Diklat Badan Kepegawaian Daerah Kabupaten Kotawaringin Timur tahun 2019 diperoleh data Pegawai yang melanjutkan pendidikan ke Jenjang S2 sebanyak I orang, mengikuti Diklat Kepemimpinan Tingkat IV sebanyak 2 orang. Penyelenggaraan Pelatihan Teknis sebanyak 2 kegiatan dengan jumlah peserta dari BKD sebanyak 26 orang. Laporan Kinerja Instansi Pemerintah Badan Kepegawaian Daerah Kabupaten Kotawaringin Timur Tahun 2019 diperoleh data pejabat yang menduduki jabatan sesuai dengan kompetensi jabatan dan kebutuhan organisasi dengan capaian sebesar $79,10 \%$, hal ini menunjukkan bahwa Sumber Daya Manusia (SDM) merupakan aset utama dan terpenting dalam suatu organisasi, pengelolaan SDM harus dilakukan secara profesional agar terwujud keseimbangan antara kemampuan SDM dengan kebutuhan sebuah organisasi. Masih terdapat pegawai yang belum menunjukkan sikap disiplin, seperti PNS datang terlambat, lupa absen pagi dan absen sore. Data Bulan Desember Tahun 2019 menunjukkan tingkat kedisiplinan PNS Badan Kepegawaian Daerah Kabupaten Kotawaringin Timur sebesar 91,11\%. Pada tahun 2019 jumlah pelanggaran disiplin PNS di Kabupaten Kotawaringin Timur sebanyak 20 orang dari 5.670 PNS yaitu pelanggaran disiplin tidak masuk kerja tanpa keterangan dari pejabat yang berwenang.

Adapun tujuan penelitian ini untuk mendeskripsi dan menganalisis pengaruh pendidikan dan pelatihan, disiplin kerja dan motivasi kerja terhadap kinerja pegawai di Badan Kepegawaian Daerah Kabupaten Kotawaringin Timur

\section{METODOLOGI}

Metode penelitian yang digunakan dalam penelitian ini menggunakan metode kuantitatif dengan menggunakan sampel sebanyak 36 orang pegawai yang ada di Badan Kepegawaian Daerah Kabupaten Kotawaringin Timur. Teknik pengambilan sampel yang 
digunakan dalam penelitian ini menggunakan sampling jenuh, teknik pengumpulan data menggunakan kuesioner / angket dengan cara memberikan seperangkat pertanyaan kepada responden, analisis data menggunakan regresi linear berganda

\section{HASIL DAN PEMBAHASAN}

\section{Koefisien Regresi}

Tabel I

Hasil Uji Analisis Regresi

\begin{tabular}{|c|c|c|c|c|c|c|}
\hline \multirow{2}{*}{\multicolumn{2}{|c|}{ Model }} & \multicolumn{2}{|c|}{$\begin{array}{c}\text { Unstandardized } \\
\text { Coefficients }\end{array}$} & \multirow{2}{*}{$\begin{array}{c}\text { Standardized } \\
\text { Coefficients } \\
\text { Beta }\end{array}$} & \multirow[b]{2}{*}{$t$} & \multirow[b]{2}{*}{ Sig. } \\
\hline & & $\mathrm{B}$ & Std. Error & & & \\
\hline \multirow[t]{4}{*}{1} & (Constant) & 3,430 & 5,847 & &,- 587 &, 562 \\
\hline & $\begin{array}{l}\text { PENDIDIKAN DAN } \\
\text { PELATIHAN }\end{array}$ & ,038 & ,131 &, 047 & ,293 & ,771 \\
\hline & DISIPLIN KERJA &, 448 & , 130 &, 511 & 3,457 &, 002 \\
\hline & MOTIVASI KERJA & ,220 & , 138 & ,272 & 1,590 & ,122 \\
\hline
\end{tabular}

a. Dependent Variable: KINERJA PEGAWAI

Berdasarkan tabel di atas dapat disajikan persamaan regresi sebagai berikut : $Y=-3,430+$ $0,038 b \times 1+0,448 b_{2}+0,220 b \times 3$

I. Nilai koefisien variabel Pendidikan dan Pelatihan (XI) sebesar $0,038 \mathrm{bX}$, hal ini berarti indeks 0,038 tidak dapat digunakan untuk memprediksi perubahan kinerja sebagai akibat dari perubahan yang terjadi pada Pendidikan dan Pelatihan (XI).

2. Nilai koefisien variabel Disiplin Kerja (X2) sebesar 0,448 bX2, memiliki arti bahwa setiap kenaikan atau penambahan I (satu) unit pada variabel Disiplin Kerja (X2) maka dapat diprediksi akan terjadi kenaikan atau peningkatan Kinerja Pegawai sebesar 0,448.

3. Nilai koefisien Motivasi Kerja (X3) sebesar 0,220 bX3, hal ini berarti indeks 0,220 tidak dapat digunakan untuk memprediksi perubahan kinerja sebagai akibat dari perubahan yang terjadi pada Motivasi Kerja (X3).

\section{Uji Koefisien Determinasi (R Square)}

Uji koefisien determinasi $R$ Square adalah untuk mengetahui besarnya pengaruh pendidikan dan pelatihan, disiplin kerja, motivasi kerja secara bersamasama terhadap kinerja pegawai.

Tabel II

Kooefisien Determinasi

\begin{tabular}{l|c|r|r|r|}
\hline Model & $\mathrm{R}$ & $\mathrm{R}$ Square & $\begin{array}{c}\text { Adjusted R } \\
\text { Square }\end{array}$ & $\begin{array}{c}\text { Std. Error of } \\
\text { the Estimate }\end{array}$ \\
\hline 1 &, $728^{\mathrm{a}}$ &, 529 &, 485 & 2,573 \\
\hline \multicolumn{2}{l}{ a. Predictors: (Constant), MOTIVASI KERJA , DISIPLIN } \\
KERJA, PENDIDIKAN DAN PELATIHAN
\end{tabular}

Dari tabel di atas, dapat dilihat bahwa nilai $R$ Square adalah sebesar 0,529 , nilai $R$ Square 0,529 diperoleh dari hasil pengkuadratan dari nilai koefisien korelasi $(\mathrm{R})$ yaitu $0,728 \times 0,728=0,529$ dengan demikian variabel Pendidikan dan Pelatihan (XI), Disiplin Kerja (X2), dan Motivasi Kerja (X3) secara simultan berpengaruh terhadap variabel Kinerja Pegawai (Y) dengan kontribusi sebesar 52,9\% sedangkan sisanya sebear 47,1\% dipengaruhi oleh variabel lain di luar variabel yang tidak diteliti.

\section{Hasil Uji T (Uji Parsial)}

I) Pengujian koefisien regresi Pendidikan dan Pelatihan

Pada variabel Pendidikan dan Pelatihan (XI) nilai signifikansi sebesar $0,77 \mathrm{I}>0,05$ dan nilai $t_{\text {hitung }}$ sebesar 0,293 $<t_{\text {tabel }}$ sebesar 2,036 hal ini berarti Ho diterima dan Ha ditolak, dengan demikian Pendidikan dan Pelatihan tidak berpengaruh signifikan terhadap kinerja pegawai.

2) Pengujian koefisien regresi Disiplin Kerja Pada variabel Disiplin (X2) nilai signifikansi sebesar $0,002<0,05$ dan nilai $t_{\text {hitung }}$ sebesar 3,457 $>t_{\text {tabel }}$ sebesar 2,036 hal ini berarti Ho ditolak $\mathrm{Ha}$ diterima, dengan demikian disiplin kerja berpengaruh signifikan terhadap kinerja pegawai.

3) Pengujian koefisien regresi Motivasi Kerja Pada variabel Motivasi (X3) nilai signifikansi sebesar 0,122 >0,05 dan nilai $t_{\text {hitung }}$ sebesar I,590 $<t_{\text {tabel }}$ 2,036 hal ini berarti Ho diterima dan $\mathrm{Ha}$ ditolak, dengan demikian motivasi kerja tidak berpengaruh signifikan terhadap kinerja pegawai. 


\section{Hasil Uji F (Uji Simultan)}

Tabel III

Hasil Uji F (Uji Simultan)

\begin{tabular}{|c|c|c|c|c|c|c|}
\hline \multicolumn{2}{|c|}{ Model } & $\begin{array}{c}\text { Sum of } \\
\text { Squares }\end{array}$ & Df & $\begin{array}{c}\text { Mean } \\
\text { Square }\end{array}$ & $\mathrm{F}$ & Sig. \\
\hline & Regression & 238,390 & 3 & 79,463 & 11,999 &, $000^{\mathrm{b}}$ \\
\hline & Residual & 211,916 & 32 & 6,622 & & \\
\hline & Total & 450,306 & 35 & & & \\
\hline
\end{tabular}

Nilai signifikansi sebesar 0,000 dan nilai $F_{\text {hitung }}$ sebesar II,999. Adapun nilai $F_{\text {tabel }}$ dengan menggunakan taraf signifikansi sebesar 0,05 dengan df (3) ; (32) diperoleh $F_{\text {tabel }}$ sebesar 2,90.

Dengan demikian nilai signifikansi sebesar 0,000 $<0,05$, nilai $F_{\text {hitung }} \mathrm{II}, 999>\mathrm{F}_{\text {tabel }} 2,90$ maka Hipotesis diterima dengan kesimpulan bahwa Pendidikan dan Pelatihan, Disiplin Kerja, dan Motivasi Kerja secara simultan (bersama-sama) berpengaruh siginikan terhadap Kinerja Pegawai.

\section{Pengaruh Pendidikan dan Pelatihan terhadap Kinerja Pegawai}

Berdasarkan analisis hasil pengujian yang dilakukan dengan menggunakan SPSS Versi 22, diperoleh nilai Variabel Pendidikan dan Pelatihan (XI) dengan nilai signifikansi sebesar 0,77I $<0,05$ hal ini berarti Ho diterima $\mathrm{Ha}$ ditolak, dengan demikian pendidikan dan pelatihan tidak berpengaruh signifikan terhadap kinerja pegawai.

Hasil penelitian sesuai dengan Teori Critical Events Model Nadler (1983), yang digunakan untuk memperoleh pemahaman mendalam mengenai prosesproses perencanaan pada setiap tahapan program pelatihan yang melibatkan perencana, Organisasi Perangkat Daerah dan Pemerintah Daerah Kabupaten Kotawaringin Timur dalam tahapan proses perencanaannya. Tahapan-tahapan dalam merencanakan kegiatan pelatihan antara lain :

I) Tahapan Identifikasi Kebutuhan Organisasi

2) Tahap Spesifikasi Pelaksanaan Tugas

3) Tahap Identifikasi Kebutuhan Peserta
4) Tahap Menentukan Tujuan

5) Tahap Memperoleh Sumber Daya Pembelajaran

6) Tahap Penyelenggaraan Pelatihan

Hasil Laporan Analisis Kesenjangan Kompetensi

PNS Badan Kepegawaian Daerah Kabupaten Kotawaringin Timur masih terdapat pegawai yang belum mengikuti diklat berdasarkan syarat jabatan.

Adanya tahapan proses identifikasi kebutuhan peserta menurut Nadler yang belum memenuhi syarat, ada beberapa peserta yang mengikuti pelatihan tidak sesuai jabatan dan tidak berhubungan dengan pekerjaan mereka sehari-hari. Hal ini terjadi karna adanya keterbatasan SDM yang ada di Perangkat Daerah serta adanya kegiatan yang sama yang berhubungan dengan tugas pokok pegawai yang akan mengikuti pelatihan.

\section{Pengaruh Disiplin Kerja terhadap Kinerja Pegawai}

Berdasarkan analisis hasil pengujian yang dilakukan dengan menggunakan SPSS Versi 22, diperoleh nilai Variabel Disiplin Kerja (X2) dengan nilai signifikansi sebesar 0,002 $<0,05$ hal ini berarti Ho ditolak Ha diterima, dengan demikian disiplin kerja berpengaruh signifikan terhadap kinerja pegawai.

Hasil penelitian sesuai pendapat Hasibuan (2017) yang menyatakan bahwa “disiplin kerja merupakan kesadaran dan ketersediaan seseorang untuk mentaati semua peraturan perusahaan dan norma-norma sosial yang berlaku”. Kedisiplinan dapat diartikan apabila pegawai selalu datang dan pulang tepat pada waktunya, menyelesaikan pekerjaan tepat waktu, mematuhi peraturan yang telah ditetapkan oleh organisasi.

\section{Badan Kepegawaian Daerah Kabupaten} Kotawaringin Timur telah menerapkan absensi online baik dengan menggunakan sistem finger print secara online menggunakan aplikasi berbasis android. Penggunaan absensi secara online akan memudahkan untuk mendapatkan data seperti jam masuk dan jam pulang, datang terlambat dan pulang cepat dapat dilihat 
dari masing-masing pegawai, tingkat kehadiran pegawai akan berpengaruh pada pembayaran Tunjangan Tambahan Penghasilan Pegawai.

\section{Pengaruh Motivasi Kerja terhadap Kinerja Pegawai}

Berdasarkan analisis hasil pengujian yang dilakukan dengan menggunakan SPSS Versi 22, ini diperoleh nilai Variabel Motivasi Kerja (X3) dengan nilai signifikansi sebesar 0, I $22<0,05$ hal ini berarti Ho diterima Ha ditolak, dengan demikian motivasi kerja tidak berpengaruh signifikan terhadap kinerja pegawai.

Menurut teori Herzberg motivasi karyawan dipengaruhi oleh adanya faktor motivator yaitu pengembangan karier pegawai. Dari hasil kuesioner dapat disimpulkan bahwa "penghargaan atas prestasi pekerjaan menjadikan motivasi dalam melaksanakan pekerjaan“ bahwa penghargaan atas prestasi kerja tidak menjadikan motivasi dalam melaksanakan pekerjaan. Penghargaan / reward yang berhubungan dengan PNS terkait promosi jabatan berdasarkan penilaian objektif antara kompetensi, kualifikasi dan persyaratan yang dibutuhkan untuk menduduki suatu jabatan, adanya pertimbangan dari tim penilai kinerja PNS atas prestasi kerja, kepemimpinan, kerjasama dan kreativitas.

Menurut Victor Vroom (1964), menyatakan bahwa kekuatan yang memotivasi seseorang untuk bekerja giat dalam mengerjakan pekerjaannya tergantung dari hubungan timbal balik antara apa yang diinginkan dan dibutuhkan dari hasil pekerjaan. Dari hasil kuesioner dapat disimpulkan bahwa "gaji dan tunjangan pegawai telah mencukupi kebutuhan pegawai“, gaji dan tunjangan yang belum mencukupi kebutuhan pegawai yang menyebabkan menurunnya motivasi kerja pegawai, begitu juga menurut pendapat Adam yang menyatakan bahwa pegawai akan membandingkan rasa keadilan pekerjaan mereka terhadap sesama rekan kerja yang akan mempengaruhi pikiran mereka terkait gaji dan tunjangan terhadap perubahan motivasi kerja.
Berdasarkan hasil kuesioner yang menjadikan motivasi kerja pada pernyataan "saya mendapatkan motivasi dan kesempatan dari tempat saya bekerja dalam pengembangan kompetensi melalui pendidikan dan pelatihan" dan "saya mendapatkan dukungan dari tempat saya bekerja dalam hal pekerjaan yang membutuhkan kreativitas dan produktivitas dalam bekerja“, hal ini sejalan dengan Pendapat Mccleland yang menyatakan bahwa karyawan akan bekerja lebih giat dan bersaing dalam hal pekerjaan untuk mendapatkan promosi jabatan dan pengembangan kompetensi melalui pelatih,

\section{Pengaruh Pendidikan dan Pelatihan, Disiplin} Kerja dan Motivasi Kerja terhadap Kinerja Pegawai

Berdasarkan hasil pengujian dengan menggunakan SPSS Versi 22, diperoleh nilai signifikansi $0,000<0,05$, sehingga dapat disimpulkan bahwa pendidikan dan pelatihan, disiplin kerja dan motivasi kerja secara simultan mempengaruhi kinerja pegawai secara signifikan.

Dari tabel kooefisien determinasi dapat dilihat bahwa nilai $R$ Square sebesar 0,529, artinya variabel pendidikan dan pelatihan, disiplin kerja, dan motivasi kerja terhadap kinerja memberikan kontribusi sebesar $52,9 \%$ sedangkan sisanya sebesar $47,1 \%$ dipengaruhi oleh faktor lain yang tidak dapat diteliti dalam penelitian ini.

Hal penelitian ini sesuai dengan pendapat Mangkunegara (2013) yang menyatakan bahwa "kinerja karyawan adalah hasil kerja secara kualitas dan kuantitas yang dicapai oleh seseorang karyawan dalam melaksanakan tugasnya sesuai dengan tanggung jawab yang di berikan kepadanya”.

Untuk meningkatkan kinerja pegawai dengan memberikan apresiasi berupa reward dan punishment kepada pegawai yang berprestasi dan bagi pegawai yang melakukan kesalahan dengan melakukan evaluasi masing-masing kinerja pegawai. Pelaksanaan 
pengembangan kompetensi melalui pendidikan dan pelatihan bagi pegawai untuk meningkatkan kinerja pegawai yang belum optimal, pegawai yang telah memiliki kinerja yang baik diharapkan juga mengikuti pelatihan untuk meningkatkan keahlian dan keterampilan yang dimilikinya, semakin tinggi pendidikan pegawai maka kinerjanya juga akan meningkat. Komunikasi yang baik antara atasan dan bawahan dalam menyelesaikan suatu pekerjaan untuk menciptakan suasana nyaman, aman dan rasa kekeluargaaan di lingkungan kerja dapat meningkatkan kinerja pegawai.

\section{KESIMPULAN}

\section{Kesimpulan}

Berdasarkan hasil analisis penelitian maka dapat ditarik kesimpulan sebagai berikut:

I. Pendidikan dan Pelatihan secara parsial tidak berpengaruh signifikan terhadap kinerja pegawai Badan Kepegawaiaan Daerah Kabupaten Kotawaringin Timur, karna diperoleh nilai signifikansi sebesar $0,77 \mathrm{I}>0,05$ dan nilai $t_{\text {hitung }}$ sebesar 0,293 $<t_{\text {tabel }}$ sebesar 2,036. Hal ini berarti indeks 0,038 tidak dapat digunakan untuk memprediksi perubahan kinerja sebagai akibat dari perubahan yang terjadi pada Pendidikan dan Pelatihan.

2. Disiplin Kerja secara parsial berpengaruh signifikan terhadap kinerja pegawai Badan Kepegawaiaan Daerah Kabupaten Kotawaringin Timur, karna diperoleh nilai signifikansi sebesar 0,002 $<0,05$ dan nilai thitung sebesar 3,457 > ttabel sebesar 2,036, artinya adalah setiap pertambahan atau kenaikan satu unit Disiplin Kerja (X2) dapat diprediksikan akan terjadi peningkatan sebesar 0,448 pada kinerja pegawai.

3. Motivasi kerja secara parsial tidak berpengaruh signifikan terhadap kinerja pegawai Badan Kepegawaiaan Daerah Kabupaten Kotawaringin Timur, karna diperoleh nilai signifikansi sebesar
$0,122>0,05$ dan nilai $t_{\text {hitung }}$ sebesar $1,590<t_{\text {tabel }}$ sebesar 2,036. Hal ini berarti indeks 0,220 tidak dapat digunakan untuk memprediksi perubahan kinerja sebagai akibat dari perubahan yang terjadi pada Motivasi Kerja.

4. Pendidikan dan Pelatihan, Disiplin Kerja, dan Motivasi Kerja secara simultan berpengaruh signifikan terhadap Kinerja Pegawai yaitu sebesar $52,9 \%$ sedangkan sisanya sebesar $47,1 \%$ dipengaruhi oleh variabel lain di luar variabel yang tidak diteliti .

\section{Saran}

Adapun saran-saran dalam penelitian ini adalah sebagai berikut :

I. Dalam rangka meningkatkan kompetensi pegawai disarankan kepada Kepala BKD Kabupaten Kotawaringin Timur untuk meningkatkan kompetensi aparatur melalui pendidikan dan pelatihan secara berkesinambungan dalam rangka meningkatkan keahlian, keterampilan dan kemampuan aparatur untuk membantu menyelesaikan suatu pekerjaan, evaluasi pasca pelatihan perlu dilakukan untuk mengetahui sejauh mana penerapan materi pelatihan dapat diimplementasikan untuk membantu menyelesaikan pekerjaan sesuai dengan bidang tugasnya, dokumen Analisis Kebutuhan Diklat (AKD) digunakan untuk memberikan rekomendasi pelatihan apa yang diperlukan oleh peserta pelatihan.

2. Disarankan kepada Kepala BKD Kabupaten Kotawaringin Timur salah satu upaya peningkatan disiplin aparatur dan kinerja pegawai melalui program sosialisasi peraturan perundang-undangan melalui kegiatan pelatihan terkait peraturan yang mengatur tentang disiplin PNS dan manajemen PNS secara berkesinambungan. 


\section{UCAPAN TERIMA KASIH}

Ucapan terima kasih yang sebesar-besarnya kepada Universitas Terbuka Jakarta, Badan Kepegawaian

Daerah Kabupaten Kotawaringin Timur yang membantu pelaksanaan kegiatan penelitian.

\section{REFERENSI}

AA. Anwar Prabu Mangkunegara. 2013. Manajemen Sumber Daya Manusia Perusahaan. Bandung : Remaja Rosdakarya.

A.H. Maslow, Frederick Herzberg, dan David McClelland. 2005. Job Satisfaction Theory.

Arikunto, Suharsimi. 2013. Prosedur Penelitian : Suatu Pendekatan Praktik. Jakarta : Rineka Cipta

Edy Sutrisno. 2016. Manajemen Sumber Daya Manusia. Cetakan ke-8. Jakarta : Prenada Media Group

Malayu S.P Hasibuan. 2017. Manajemen Dasar, Pengertian, dan Masalah, Edisi Revisi. Jakarta : Bumi Aksara

Nadler, Leonard. 1983. Designing Training Programs : The Critical Events Model. USA : Addison Wesley Publishing Company

Rivai, Veithzal. 20I I. Manajemen Sumber Daya Manusia Untuk Perusahaan Dari Teori ke Praktik.Jakarta: Raja Grafindo Persada

Silalahi, Bennett. 2000. Perencanaan Pembinaan Tenaga Kerja Perusahaan, Lembaga Pendidikan dan Pembinaan Manajemen. Jakarta : Pustaka Binaman Pressindo.

Victor. H. Vroom. 1964. Work and Motivation. New York : John Wiley \& Sons.

Wibowo. 20II. Manajemen Kinerja. Jakarta : PT. Raja Grafindo Persada 